\title{
IMPACT OF JUDICIAL EFFICIENCY ON FINANCIAL LEVERAGE
}

\author{
AROOJ MASHKOOR \\ HASSAN RAZA \\ National University of Modern Languages, Islamabad, Pakistan
}

\begin{abstract}
The objective of this study was to investigate the impact of judicial efficiency on financial leverage of 100 firms, listed on Karachi Stock Exchange (KSE), over the period of 20102012. Data were collected from Balance Sheet Analysis issued by State Bank of Pakistan (SBP) and reports of Lahore High Court, based on 36 districts. The study also uses explanatory variables including profitability of firms, size of firms, tangibility of assets and growth opportunities that support the judicial efficiency to measure the financial leverage of firms. The results indicate that in worsening judicial system the size of firm, tangibility of assets, and profitability, all have a significant impact but negative relationship with leverage ratios. These results demonstrate in the light of pecking order theory. Only growth has positive significant impact on financial leverage of firms. Finally, result also indicates that the judicial efficiency has a negative relationship but non-significant with financial leverage. The study concludes by discussing policy implications.
\end{abstract}

\section{INTRODUCTION}

Investors, in making lending decisions, when going to lend the money to borrower the rational creditors, banks and sensible companies will try to investigate or discover the nature of the borrower, as well as the lawful insurance accessible to them in case of the borrower default. At the point when the authorization of moneylenders' rights is poor or expensive regarding administrative expenses and legally time taking transactions, by an alternative instrument lenders are trying to ensure themselves. Because of that purpose, moneylenders as collateral request the fixed security resources, personal guarantees are required, and choose those borrowers with probably low level risk, for example, affluent and well off people, large firms size, and prefer to increase short term loans.

There are two types of collateral, including inside collateral and outside collateral. It is very important to recognize inside and outside collateral, and between personal and real guarantees. Inside guarantee is physical resources or assets owned by the borrower, and it is basically used to request lenders need, in case of default. Outside collateral is resources or assets posted by external grantors, and it expands the potential loss of the borrower in case of insolvency. Therefore, the relationship should be stronger among risk and guarantee in case of outside collateral, given that inside guarantee does not provide additional losses to the borrower in default situation. Without an individual surety or collateral of fixed resources, borrowers are refused for financing under an inefficient judicial system. This results in less lending in the economy. Also, financial structure of many companies' reduced tendency to finance short-term lenders and only wanting to expand the scope of the progress of the short maturity.

Current development in finance and law literature demonstrated that the development of capital markets is highly dependent on the significance of institutional improvement and lenders' right protection. Various research studies have focused on the country through the contrasts in the nature of law and regulations and protection available to creditors, minority shareholders and the implications of all this on the advancement of the financial framework, and corporate governance, and funding patterns (e.g. Shleifer \& Vishny 1997; La Porta, Lopez-de-Silanes, Shleifer \& Vishny, 1996; 1997; 1998; 2000; Dehesa, Druck, \& Plekhanov, 2007; Djankov, McLiesh Shleifer, 2007).

Previous literature have given proof on inside country judicial effectiveness and corporate financial choices in corporate. Pinheiro and Cabral (1999), Jappelli, Pagano and Bianco (2005) and Magri (2006), in their studies posited that judicial efficiency is related to the general level of the credit in the economy. The goal of this paper is to take step to fulfil the observational distance by giving proof on the productivity of region high courts and its effect on the financial leverage structures of firms in Pakistan. 
Numerous ways, in which firms could change extra time to the target debt ratio, are proposed in the optimal capital structure theories. In corporate, there is the use of diverse mixture of equity, debt and hybrid security. Corporate studies recent improvements demonstrate the ideal capital structure, that it is not limited only to choose a certain proportion of equity or debt ought to be utilized, but also involve decision related to debt, including the choice of short-term debt or long term debt (Leland \& Toft, 1996; Myers, 1977a; Yi, 2005)

In the research on a study on determinants of capital structure of Pakistani listed firms, Hijazi and Shah (2004) reported that in a total debt of listed firms include the greater percentage of short term debts instead of long term debt. Additionally, Demiriguc-Kunt and Maksimovic 1999, Corner et al., 2001, report in developing countries the percentage of short terms debt is higher.

Across countries, there is a rich variety in the legal rights of lenders and in the requirement of contracts. Relatively little is thought about the direct expenses of being spotted in a country with powerless laws and poor property rights insurance. Therefore, when banks offers credit to firms in country having weak creditor rights and poor authorize capacity of agreement, credit spreads will be higher. Additionally, banks will reduce loan sizes and shorten loan maturities.

Recent studies have demonstrated that protected rights of the property are connected with higher estimations of securities exchanges and a higher number of listed firms (La Porta et al., 1997); larger investments made from the external funds (DemirgucKunt and Maksimovic, 1998, Rajan and Zingales, 1998)greater value of the listed firms in relation to its benefits (Claessens et al., 2002; La Porta et al., 2002b), and more utilization of outside finance (La Porta et al., 1997, 1998, 2002a).

Other recent studies examine the effect of the judicial efficiency on the amount of loans and its rate of interest. Majnoni and Laeven (2003), studied utilization of total country level information on interest rate spreads from banks' financial statements and looked at the impact of legal property protection rights on the expense of bank credit. Jappelli et al. (2005) and Pinheiro and Cabral (1999) report that even inside a region (country),that there is a regional difference in the impact of judicial efficiency on the amount of loan and its rate. The creditors' power theory proposes that when credit providers become capable and powerful, they can get the control of the firm by implementing contracts through judicial system at low expense and time, they will be more capable, additionally, eager to build and extend the time to get the loans matured.

Inefficient judicial system brings down the chances of recovery of loan by those money borrowers who are facing monetary hardships and those who are opportunistic. When loan has a long maturity, then there are less chances of loans recovery. If taking into account short term loans, creditors are continuously reviewing and screening financial position and attitude of money borrowers and they can refuse to extend the date of maturity of loans when they see the demand of loans in the market. This attitude may restrict short term loan providers' ability to use the judicial system for the recovery of their loan. Interestingly, long term nature of the loan providers need to hold up till the loan maturity date, i.e. they can't get their money back before the maturity date regardless of the possibility that he realizes their financial position is down falling with time. This implies that the long term loan providers can't utilize the preventive measures before maturity like short term loan providers. Rather lenders having long term loan will need to fall back on court in any situation, such as, a borrower is being unable to pay off his loan, etc. Consequently court will protect the rights of loan providers, and the efficient judiciary will be authorizing the contracts relating loans and it is the most significant determinant of long term loan financing. Here a query arises, 'in Pakistan why do lenders who are facing down fall are afraid of or reluctant to go to the courts against such organisations? Reason can be the inefficient judicial process, expensive methodology, slow and time consuming process of courts prevalent in Pakistan.

This paper's basic objective is to discuss the finance and law relationship and a good effort to fill the observational gap by giving proof on the effect of efficiency of judicial system on listed firms' financing decisions in Pakistan. The particular objectives of the study are:

a) Evaluating the impact of effectiveness of judicial system on listed firms' leverage decision in Pakistan.

b) For capital market development, highlighting the significance of efficient judicial system in Pakistan

c) To highlight the significance of particular characteristics of the firm on which the efficiency of the judicial system is not high or inefficient in financing decision

This study helps to present immediate and in decomposition impact of effectiveness of judicial system on listed firms' leverage ratio. Inside measure the efficiency of the judiciary is controlled by the effect of the structure of the nation through cooperation with quarterly variety of companies, which are arranged on the basis of their characteristics. Screening analysis can be very helpful to know the scope up to which 
compounding efficiency of the judicial system affects small and big companies' leverage ratio; those firms having greater and minimal guarantee and those firms which are having less and greater unpredictable money streams. These types of examination are useful in superior strategy plan.

The study will show the significance of efficient judicial system in the capital market of Pakistan for its development. Consequences of the research recommend that the efficiency of the judicial system is very important justification of the listed companies' leverage structure in Pakistan. Policy makers and their partners i.e. SECP, all three stock markets and SBP must understand that the advertisement of long term obligations can't be established but powerful contracts can be formed.

\section{LITERATURE REVIEW}

This part reviews the theoretical structure surrounding a judicial proficiency to financing choices, i.e. the amount of financial leverage. In doing so, preview from already existing applied plus practical research studies is selected. The companies' decisions about financing are examined inexistence of ineffectual judicial system. Every perspective is independently discussed in the certain passages in relationship with ineffectiveness of judicial framework.

\section{Judicial Efficiency and Leverage}

Judicial efficiency is controlled by the way the legal guidelines are actually applied. The judicial frameworks assume an essential part in economic development on the grounds that they have impact in the process of determining and strengthening of property rights and additionally in the evaluating of contract implementation (Arias and Arias, 2007). The principle function of the judicial framework are to ensure the implementation of the legal standards.

Lawful assurance to lenders as well as authorization probably similar by legal framework assumes a significant part in loaning agreements. Protected security might not be enough alone to avoid participants to the credit agreements from taking part in strategic conduct. As argued by Galindo (2001, p.16): 'In case of inefficient organizations might be possible, the alternate participants ought to obtain profits from disowning on the mortgage agreements might be marked sufficiently to keep the agreement's acknowledgment. Therefore, the capacity of these establishments to adjust the participants considerations to the statements of debt agreements may turn into a tool of advancement of monetary expansiveness.'

In an efficient judicial system, there are lower chances of borrower's opportunistic behaviour. Borrowers will face minor default expenses in an inefficient judicial system. At the point when borrowers already know that through defaulting on the loan they can get more benefits, they will decide to default even when they are finically stable (Eaton \& Gersovitz, 1981; Jappelli, Pagano \& Bianco, 2005). Creditors will be extremely careful and particularly in making credit, where borrowers have less motivation to reimburse the loan. Uncertainty about the refund of loan will be increased by borrower in a situation of inefficiency of judicial system (Bae \& Goyal, 2009). Interest rate will charge higher by lenders when credit risk increases.

\section{Firms characteristics and judicial efficiency}

Creditors give loan to only those borrowers who have the capacity to repay the amount of loan with its interest. The literature recommends there are some business aspects that provide knowledge, related to companies as well as projects nature that the companies attempts. Firm's size as well as collateral proposed towards the credit is such characteristics act as proxies for knowledge accessibility regarding the firm, uncertainty as well as the venture projects nature.

In the following firm characteristics also include the profitability and growth that have broadly been utilized as a part of capital structure analysis. Those attributes don't own direct effect on company's capital framework only. Moreover, their communication along judicial efficiency may hold extra impact on company's capital framework.

\section{Firm size}

According to Pettit and Singer (1985), the imbalance data drawback is extreme for small size firms, while they think that is valuable to create and deliver data regarding themselves. That's the reason small firms are viewed as more difficult than large firms. It is very important to differentiate the high and low quality borrower at the time of lending but the insufficient amount of information creates difficulty for lenders. This will expand the risk of poor selection. Inefficient implementation of judiciary system, lenders will not have the capacity to recover everything of their credit from low-quality borrowers,

Large firms have higher capability for consuming negative external shocks and are thought to be more diversified because of their huge resources base when contrasted with small size firms (Titman \& Wessels, 1988). The popular well-known phrase to discuss this sensation is 'too large to flop', which recommends the large size companies bear a minor chances of declining into monetary trouble as well as insolvency, but the small 
scale firms are opposite to them. As inefficient lawful application creates problems for financer to recoup their credit from companies in monetary misery, financers will be charges superior prices on financing to small size firms; either may be refuse to give credit to small firms in some cases. Kumar, Rajan \& Zingales (1999), utilizing information on firm's size as a part of Western European nations, found that efficient judicial system are connected with greater average firm size. The effects are greater for commercial enterprises where physical resources are less.

The above discussion about firm size suggests that efficiency of judicial system has more value for firms in small size. When the efficiency of judicial system is lower, credit stream decreases to small firms.

\section{Collateral}

The numerous problems connected with data asymmetries can resolve through Collateral. Coco (2000) examines that collateral can resolve different issues caused by irregular information in loan contracts, for example, issues associated with project evaluation, risk about nature of the project, borrowers riskiness, as well as moral risks. Chan and Kanatas (1985) explore that guarantee may support creditor and also borrowers, which have conflict regarding project value because of asymmetry information. As guarantee has a more secure worth as compared project which cash streams will collect later, creditors perceive more secure lending towards collateral, than to take loan towards a risky projects.

Fears related to the riskiness of borrowers or projects can be solved through collateral. Opportunistic borrowers won't prefer to promise valuable resources as collateral towards credits, particularly borrowers along with uncertain plans. Different researches like Bester (1985), Besanko and Thakor (1987), Chan and Thakor (1987) demonstrate that the collateral's worth in addition to average uncertainty of projects are conversely associated; so, profitable guarantees recommend minor risk in project. By determining that data imbalance issue, the credit markets productivity expands by surety. Taking after identical discussion lines, Bester (1985:1987) explore that knowledge regarding dissimilar borrowers poor selection issues disclose through collateral. Moreover, when borrowers realize that their misconduct can bring about loss of the profitable securities, they will ideally neither take part in good hazard projects (Barro, 1976).

The greater part of previous discussion, securities remove issues are associated with imbalance information, subsequently it can be anticipated that ineffectiveness of judicial system influences entire borrowers similarly.
Borrowers along with profitable collateral wouldn't tackle difficult data asymmetry issues and would be less influenced as judicial proficiency decreases. Inspite of the above expectation regarding collateral, leverage and judicial efficiency, as examined in Galindo's (2001) study, it might be possible to lose the collateral significance, if creditors feel that they can't get it back through judicial procedure. Magri(2006) explained that in case ifborrower will be bankrupt, banks will face minor misfortunes, if the borrowers have more tangible resources in light of the fact that these benefits can act as collateral. Since development options get to be useless when borrowers tackle insolvency and simply recognize the importance of physical assets in a business sector, lender's wish to provide to borrowers along with additional physical resources. That's very fascinating to learn which of the above mentioned challenging discussions remain up into the applied enquiry of judiciary effectiveness and also leverage utilized by recorded enterprises in Pakistan.

Blended applied proof about association of leverage and physical assets exist, when the former is participated with a proxy for effectiveness of judicial framework. Fan, Titman, and Twite (2008) utilized two different proxy for assets tangibility and collaborate them along with a list of crime which quantify how ineffective judicial framework of stated nation securing the lenders rights. Their first proxy for assets tangibility can be evaluated by market to book ratio, it has critical impact on firm's capital structure in many immoral nations and poor judicial frameworks. Although, other proxy evaluated by total tangible assets to total assets, isn't factually important.

An empirical result of Fabbri and Padula (2004) found that, an expression of the fact that weak legal system will redistribute credit against borrowers for more resources. They found that areas where judicial system is weak, credit accessibility to inferior households decreases yet to well off households, it raises. Their outcomes imply that it may be because of the reality that inefficient lawful framework redistribute credit against borrowers for more assets.

\section{Growth}

Jensen and Meckling (1976) contended that for growing firms' business expenses of liabilities are greater, while supervisor in these organizations possess the incentives to contribute ideally. Moreover, seize money from bondholders to shareholders. The growing companies have further alternatives to put resources into those projects which consider as risky. Moneylenders expect that those firms can take moral risks for them. Subsequently, moneylenders will be wary of giving credit to developing firms or charge higher interest. 
Titman and Wessels (1988), posited that expect opposite relationship among leverage and growth opportunities, however from distinctive point. They observe that while growth opportunities can't be offered as guarantee and don't create current pay, companies that have greater wealthy resources in sort of development chances are relied upon to have less leverage proportion. Myers (1977) recommends that the growth chances are optional; subsequently, thus they shouldn't be sponsored with pricey leverage. Besides, fixed resources consider as sunk expenses and can invest with leverage ideally.

Therefore, in the light of above discussion, a few observational studies discovered the negative relation among company's leverage ratio and growing opportunities. These reviews incorporate Titman and Wessels (1988), Barclay and Smith (1995) and Rajan and Zingales (1995).

\section{Profitability}

Myers (1984) contends that organizations favour internally created finance to external finance and debt to equity funds. This inclination of firms called as pecking request. That's a result of irregular data; the outside funds are more as compared to inside funds. Moreover, the expense of raising equity is greater as compared to the debt costs. Expect lower percentage of debt financing in case of profitable firms. In the view of double taxation, the inverse relation is expected among leverage and profitability. Auerbach (1979) suggested that organizations have incentives to hold income to keep away from dividend taxes (Magri, 2006). It's anticipated that organizations will suppose that it's hard to increase outside funds and also will disperse low benefit where law courts are wasteful. Where judicial system is inefficient, organizations will think hard to raise external funds and will disperse less benefits.

\section{Hypotheses}

In perspective of the aforementioned theoretical framework and experimental proof, only the null hypotheses are recorded for the following testable hypotheses. The null hypotheses can be determined over ordinary way where zero relationship is proposed among the explanatory and explained variables.

\section{Leverage ratios hypotheses}

Hypothesis 1. In districts where judicial inefficiency is higher listed firms have less leverage ratios than non-listed firms. Hypothesis 2. Inefficiency of judicial system increases, the leverage ratios of large size firms more than small size firms.

Hypothesis 3. In districts where judicial system is not efficient, firms have low leverage ratios with little collateral.

Hypothesis 4. In districts where judicial inefficiency is higher, growing firms have less leverage ratios than non-growing firms (growth).

Hypothesis 5. In the absence of judicial efficiency, higher profitable firms having low leverage ratios than less profitable firms.

\section{METHODOLOGY}

In this section, source of data, sample size (population) and variables are described with measurement methods. Study has selected convenience sampling methodology. Total 100 companies are selected from different industries from 2010 to 2012 of Pakistan, which are listed in Karachi Stock Exchange KSE. The paper investigates the judicial efficiency impact on financial leverage. The first variable is judicial efficiency that is independent variable. Study found the data on judicial statistics from annual reports of High Court, Lahore that was based on 36 districts. For judicial statistics the sample duration is 2010 to 2012.

The data in the study is taken from secondary, derived the financial data of 100 registered firms in KSE from 'Balance Sheet Analysis Of Companies (Nonfinancial) Listed at Karachi Stock Exchange'. The data is the publication of State Bank of Pakistan (SBP). Study selected the sample period for the analysis of balance sheet from 2010 to 2012.A data is populated from KSE using annual financial statement of the companies.

\section{MEASURES}

\section{The leverage measure (Dependent variable)}

The leverage basic meaning is Long term debts. The debts in Short term nature will not be used as a source of financing but usually provided by suppliers to firms for comfort. Debts include both long term and short term. Some studies use only long term debts as a proxy for leverage and some use both short plus long term debts. Earlier researches utilized just long term debts as a leverage proxy (Ferri \& Jones, 1979; Marsh, 1982; Castanias, 1983; Bradley et al., 1984; Kim \& Sorensen, 1986). In the study of Titman and Wessels (1988) also 
include short term debts with long term debts as a leverage proxy.

Although, majority of the researches like Rajan and Zingales (1995), Aivazian, Booth, and Demirguc-Kunt, (2001), and Fan et al. (2008) also used both short and long term debts as a proxy of leverage ratios. Major source of financing of corporate sector still rely on banks, in developing countries like Pakistan, in capital structure researches, short nature financing cannot be ignored. In developing economies, the firms mostly rely for financing on banks, which is normally short term in nature. That is one reason behind earlier studies found by Booth et al. (2001), to use short term debts in leverage ratios.

This study uses two proxies to measure the leverage ratios as LEV1 and LEV2. As proxy for LEV1 the ratio of long term debt to total assets is used and for LEV2 using the ratio of total debts to total assets. In total debts include both long term plus short term debts.

\section{LEV1 $=\underline{\text { Long term debts }}$} Total assets

LEV2 $=\underline{\text { Total debts (short term }+ \text { long term) }}$

Total assets

\section{Judicial Efficiency (Independent variable)}

Three types of proxies have been used to measure judicial efficiency in earlier studies for a single country. Proportion of awaiting cases to numerous liable cases initiated in a single year (Fabbri, 2002; Fabbri \& Padula, 2004; Jappelli et al., 2005). Proportion of awaiting cases per thousand person in a certain district/region (Jappelli et al., 2005). At last, final proxy includes the average period consuming by province/district court from the initiation of cases to disposal (Magri, 2006).

To measure judicial efficiency, the first proxy is not used, because it's prepared by Business international corporation (BIC), it includes subjective index that's not available in Pakistan's districts. The third proxy average time consuming by province/district court in deciding cases is also not used, because of data unavailability. The second proxy is used in study to measure judicial efficiency due to suitability and availability of data, where unresolved cases are standardized by a few base figures, such as, number of cases initiated in a year (JE1), number of cases disposed of in a year (JE2), given district population (JE3) and at last, also use number of pending cases in banking court (JE4).

$\mathrm{JE} 1=\underline{\text { Number of pending cases in a given district at the }}$ end of the year

Number of cases initiated during the year

$J E 2=$ Number of pending cases in a given district at the end of the year

Number of cases disposed-off during the year

$J E 3=$ Number of pending cases in a given district at the end of the year

Population of district measured in thousands JE4 $=$ Number of pending cases in banking court (where such courts are present)

Population of district measured in thousands

When quantity of pending cases is greater in comparison to disposed-off cases, the result is greater value of JE that reduce the high court's efficiency. That result is showing that high courts are not able to fulfil the interest put on it as compared to other area high courts.

\section{Explanatory variables}

\section{Growth}

Different proxies are used for growth opportunities. According to Adam and Goyal (2008), the ratio of Market value of assets to Book value of assets is the best proxy to measure the growth. In addition, number of studies concerning investment or debt maturity investigations use ratio of M.V/B.V of assets as a proxy for growth opportunities. This study also uses ratio of M.V/B.V of assets as proxy to measure the growth options.

$$
\begin{aligned}
\text { Growth } & =\text { MVBV } \\
& =\underline{\text { Market value of assets }}
\end{aligned}
$$

\section{Firm size}

This study uses proxy to measure firm size as Natural Logarithm of total assets. Smaller firms are liable to more insolvency as compared to larger firms, because larger firms' businesses are spread out and their risk is also diversified, whereas, smaller firms always aim at settling their gap of information and smaller firms are so alert in better dealing for the purpose of external financing with lenders (Titman \& Wessels, 1988). These results are less reliant of smaller firms on external sources of finance than larger firms, which have lower asymmetry information. So, larger firms have a greater access to the debt financing, as the cost of debt is also low. Another main advantage of larger firms is that they have very less variation in their earnings as smaller firms normally have, so this makes larger firms to get financing from external sources particularly debt a more better option.

Size $=$ Natural Logarithm of total assets 


\section{Tangibility}

Tangibility signifies the extent to which the firm is financed by the fixed assets. Normally, firms with more tangible assets tend to have less leverage and accordingly it gets to be complex for them to utilize such assets as guarantee for producing the additional funds which may disclose the firm to insolvency. When making lending decision lenders feel more confident to use tangible assets as collateral has more stable value in market (Chan \& Kanatas, 1985). Then again, tangibility might be improve the firm ability to utilize fixed assets as guarantee at whatever point outer funds are obliged inferable from the reason that financed in assets are diverse, which might reduce the possibilities of insolvency. To measure the firm's tangibility the proxy as the ratio of total net fixed assets to total assets is used.

Tangibility $=\underline{\text { Total net fixed assets }}$ Total assets

\section{Profitability}

The two types of proxies have been used to measure firm's profitability in earlier studies, i.e. Return on equity (ROE) and Return on assets (ROA) (Gill et al. \& Muzir, 2011; Alsawalhah \& Shubita, 2012). This study uses only one proxy for profitability that is ROA as the ratio of Net income to Total assets. The most popular and widely used financial tool is ROA to certify the strength and returns level that the firm has generated.

$$
\text { Profitability }=\frac{\text { Net income }}{\text { Total asset }}
$$

TABLE 3

\begin{tabular}{|c|c|c|}
\hline $\begin{array}{c}\text { Variable } \\
\text { names }\end{array}$ & Proxies & Measured by \\
\hline Leverage1 & LEV1 & $\begin{array}{l}\text { Ratio of long term debts to } \\
\text { total assets }\end{array}$ \\
\hline Leverage 2 & LEV2 & Ratio of total debts to total assets \\
\hline Growth & MVBV & $\begin{array}{l}\text { Market value per share/book } \\
\text { value per share }\end{array}$ \\
\hline Profitability & PROF & $\begin{array}{l}\text { Ratio of net income to total } \\
\text { assets }\end{array}$ \\
\hline Tangibility & TANG & $\begin{array}{l}\text { Ratio of net fixed assets to } \\
\text { total assets }\end{array}$ \\
\hline Size & SIZE & Natural logarithm of total assets \\
\hline $\begin{array}{l}\text { Judicial } \\
\text { efficiency }\end{array}$ & JE & $\begin{array}{l}\text { Ratio of pending cases at the } \\
\text { end of the year to disposed off } \\
\text { cases during the year }\end{array}$ \\
\hline
\end{tabular}

Measurements \&variables name
This table 3 represents the all variable names that are used in the research including dependent, independent and explanatory variable and the proxies that are used to measure the variables. These proxies have been broadly utilized as a part of capital layout research.

\section{Model Specification}

The multiple regression analysis was done to study the judicial efficiency impact on financial leverage. There is one dependent variables financial leverage structure, so we apply and develop one regression model. The regression model for Leverage

$$
\begin{gathered}
\mathrm{Y}_{\mathrm{it}}=\beta_{0}+\beta_{1} \text { SIZE }_{\mathrm{it}}+\beta_{2} \text { TANG }_{\mathrm{i}, \mathrm{t}}+\beta_{3} \text { PROF }_{\mathrm{i}, \mathrm{t}}+ \\
\beta_{4} \text { GROWTH }_{\mathrm{i}, \mathrm{t}}+\beta_{5} \mathrm{JE}_{\mathrm{i}}+\varepsilon_{\mathrm{it}}
\end{gathered}
$$

The dependent variables Leverage ratio is denoted by Yit for firm $i$ at time $t$. The other variables are consider as explanatory variables including SIZE, TANG, PROF, and GROWTH(MVBV). At last, the independent variable is judicial efficiency that can by JE.

$\varepsilon=$ Error term or residual which represents the factors affecting the dependent variable not accounting for by the model. Its average value is taken as zero (Gujrati, 2004).

\section{RESULTS AND DISCUSSION}

This section includes descriptive statistics plus outcomes from regressions analysis for leverage ratios.

\section{Descriptive Statistics}

Table 4 shows the review of descriptive statistics of given variables expressed in regression model. To present overall explanation of 100 companies data, those statistics were created utilized as a part of the model also empower the investigators display the information for any apprehensive figure. In the basic measures of descriptive analysis includes the standard deviation, median, mean, the maximum and minimum estimations of variables.

The mean values of dependent variable LEV1 plus LEV2 are 0.321 and 0.772 , with standard deviation at 0.409 and 0.482 . The minimum and maximum values of LEV1 are 0.00 and 4.405. The maximum value of LEV2 is 4.659 and the minimum value is 0.00 . At last the median of LEV1 and LEV2 are 0.202 and 0.686 .

The descriptive statistics of explanatory variables are discussed further, which are considered as independent variables. The mean value of SIZE is 6.175 and standard deviation 0.651with global minimum and maximum values at 4.411 and 7.753 , the median of SIZE is 6.199 . 
The variable profitability (PROF) has minimum value of is 1.386; further standard deviation and median values -140.12 and maximum value is 32.50 , which mean value are 15.572 and 2.855.

TABLE 4.1

All variables Descriptive statistics

\begin{tabular}{lcccccc}
\hline \multicolumn{1}{c}{ Variables } & Mean & Median & Std. Dev. & Maximum & Minimum & Observations \\
\hline LEV1 & 0.321 & 0.202 & 0.409 & 4.405 & 0.000 & 300 \\
LEV2 & 0.772 & 0.686 & 0.482 & 4.659 & 0.0001 & 300 \\
SIZE & 6.174 & 6.199 & 0.651 & 7.753 & 4.411 & 300 \\
TANG & 0.623 & 0.615 & 0.192 & 0.998 & 0.0116 & 300 \\
GROWTH & 11.541 & 1.585 & 71.028 & 828.78 & -496.85 & 300 \\
PROF & 1.386 & 2.855 & 15.572 & 32.500 & -140.12 & 300 \\
JED & 37.645 & 38.321 & 2.209 & 39.945 & 34.670 & 300 \\
\hline
\end{tabular}

TABLE 4.2

Correlation Matrix between the variables

\begin{tabular}{lccccccc}
\hline & LEV1 & LEV2 & SIZE & TANG & GROWTH & PROF & JED \\
\hline LEV1 & 1.000 & & & & & & \\
LEV2 & 0.752 & 1.000 & & & & & \\
SIZE & -0.516 & -0.565 & 1.000 & & & & \\
TANG & 0.245 & 0.149 & -0.446 & 1.000 & & & \\
GROWTH & -0.097 & -0.175 & 0.052 & -0.118 & 1.000 & & \\
PROF & -0.474 & -0.527 & 0.222 & -0.153 & 0.497 & 1.000 & \\
JED & 0.030 & 0.020 & 0.030 & -0.016 & -0.071 & -0.186 & 1.000 \\
\hline
\end{tabular}

TABLE 4.3

Regression results of LEV1

\begin{tabular}{lcccc}
\hline \multicolumn{1}{c}{ Variable } & Coefficient & Std. Error & t-Statistic & Prob. \\
\hline SIZE & -0.445748 & 0.131282 & -3.395361 & 0.0008 \\
TANG & -0.702372 & 0.120304 & -5.838299 & 0.0000 \\
GROWTH & 0.001098 & 0.000273 & 4.024576 & 0.0001 \\
PROF & -0.010166 & 0.000871 & -11.67327 & 0.0000 \\
JED & -0.002269 & 0.003717 & -0.610339 & 0.5423 \\
C & 3.597625 & 0.783390 & 4.592383 & 0.0000 \\
Cross-section fixed (dummy variables) & & & \\
R-squared & 0.936649 & Mean dependent var & 0.320552 & \\
Adjusted R-squared & 0.902862 & S.D. dependent var & 0.409209 & \\
S.E. of regression & 0.127538 & Akaike info criterion & -1.011588 & \\
Sum squared resid & 3.171858 & Schwarz criterion & 0.284736 & \\
Log likelihood & 256.7382 & Hannan-Quinn criter. & -0.492797 & \\
F-statistic & 27.72204 & Durbin-Watson stat & 2.585149 & \\
Prob(F-statistic) & 0.000000 & & & \\
\hline
\end{tabular}


TABLE 4.4

Regression results of LEV2

\begin{tabular}{lcccc}
\hline \multicolumn{1}{c}{ Variable } & Coefficient & Std. Error & t-Statistic & Prob. \\
\hline SIZE & -0.648210 & 0.104693 & -6.191521 & 0.0000 \\
TANG & -0.910532 & 0.095939 & -9.490738 & 0.0000 \\
GROWTH & 0.000865 & 0.000218 & 3.973717 & 0.0001 \\
PROF & -0.011318 & 0.000695 & -16.29684 & 0.0000 \\
JED & -0.003834 & 0.002965 & -1.293224 & 0.1975 \\
C & 5.492354 & 0.624730 & 8.791562 & 0.0000 \\
Cross-section fixed (dummy variables) & & & \\
R-squared & 0.970992 & Mean dependent var & 0.772174 & \\
Adjusted R-squared & 0.955521 & S.D. dependent var & 0.482252 & \\
S.E. of regression & 0.101708 & Akaike info criterion & -1.464209 & \\
Sum squared resid & 2.017172 & Schwarz criterion & -0.167885 & \\
Log likelihood & 324.6313 & Hannan-Quinn criter. & -0.945418 & \\
F-statistic & 62.76153 & Durbin-Watson stat & 2.293666 & \\
Prob(F-statistic) & 0.000000 & & & \\
\hline
\end{tabular}

The minimum and maximum values of variable tangibility (TANG) are 0.012 and 0.998 , who's mean and median values are 0.624 and 0.615 , its standard deviation is 0.192 . The last explanatory variable is Growth opportunities that is denoted with GROWTH measured as MVper share/BV per share (MVBV). The mean values of GROWTH is 11.541, whose median and standard deviations are 1.585and 71.028. The minimum and maximum value of GROWTH is -496.85 and 828.78 .

The mean value of Independent variable judicial efficiency (JED) is 37.645 , with standard deviation and median values are 2.209 and 38.321 with minimum and maximum values 34.670 and 39.944 .

The table 4.2 is showing the correlation matrix among variables that are used in regression demonstrate that there is no major issue of multicollinearity among varaiabls. LEV1 and LEV2 are negatively correlated with SIZE, GROWTH and PROF that consider as explanatory variables and they are positively correlated with TANG and JED.

\section{Regression Analysis}

The regression model results are discussed under this section. Leverage regression results are presented below.

\section{Leverage regression results}

Results of regression model are shown in table 4.3 and 4.4, which test the stated hypothesis that impact of judicial efficiency on leverage ratios by using Panel least square method. Table 4.3 described the results of regression where dependent variable is LEV1 which measures as ratio of long term debts to total assets, table 4.4showing the results of regression whereLEV2is dependent variable which measures as ratio of total debts to total assets. In tables 4.3 and 4.4 the first column represents the name of independent variables. The second column indicates the coefficients of these variables where LEV1 and LEV2 are taken as dependent variable, third column is showing standard errors, Fourth column is showing t-statistics, last one is the column of probability of LEV1 and LEV2, which shows the statistical significance level at $1 \%, 5 \%$, and $10 \%$. The study considers $5 \%$ statistical level to check the significance. Strong standard errors present in brackets. Bottom section of the table indicates R squared, adjusted $\mathrm{R}$ squared, F-Statistics and some other tests.

The outcomes of the multiple linear regression propose that a significant proportion of the total variation in LEV1 (D.V) and LEV2 (Dependent variable) was projected by explanatory variable.

The variable SIZEi,t of firm that is statistically significant at $5 \%$ level $(\mathrm{t}=-3.395, \mathrm{p}<0.05)$ in LEV1 and $(t=-6.192, p<0.05)$ in LEV2 with every one point. Firm SIZEi,tis negatively correlated with both LEV1 and LEV2, the co-efficient are (-0.446) and (-0.648). A negative or positive sign indicates the direction of relationship. SIZE has negative relationship with LEV1 and LEV2. As size increased by one standard point, it will decrease the LEV1 by 0.446 and LEV 2 by approximately, at 0.648 standard deviation.

The variable TANGi,tis statistically significant at $5 \%$ level $(\mathrm{t}=-5.838, \mathrm{p}>0.05)$ in LEV1 and $(\mathrm{t}=-9.491$, $\mathrm{p}<0.05)$ in LEV2 with every one point. The co-efficient 
of TANG in LEV1 is (-0.702) and in LEV2 is (-0.911) that's mean TANG is negatively correlated with both LEV1 and LEV2, both have negative relationship. As TANG increased by one unit, LEV1 will decreases by 0.702 and LEV2 will decrease by approx 0.911 . In case of long term financing, tangibility of assets consider important.

The variable PROFi,tis related significantly to both LEV1 as well asLEV2at5\% level $(\mathrm{t}=-11.673, \mathrm{p}<0.05)$ and $(\mathrm{t}=-16.297, \mathrm{p}<0.05)$ with every one point, whereas PROF is negatively correlated to both LEV1 and LEV2. The coefficient are (-0.010) and (-0.011). Anyhow, the economic significance of variable profitability (PROF) is lower. When PROF of firm increases one standard deviation, it will decrease LEV 1 by 0.010 and LEV2 by 0.011 respectively.

The variable MVBVi,t, that is denoted with Growth are statistically significant at $5 \%$ level $(\mathrm{t}=4.025, \mathrm{p}<0.05)$ in LEV1 and $(\mathrm{t}=3.974, \mathrm{p}<0.05)$ in LEV2 with every one point, the coefficient are 0.0011 and 0.0009 that is positively correlated with LEV1 and LEV 2. This indicates that growth opportunities positively affect dependent variables LEV1 and LEV2. As MVBV positive coefficient indicates that increase in one unit of MVBV will also increase by0.0011units in LEV1 and 0.0009 in LEV2respectively. Although positive outcomes of growth opportunities on financing are credible for small, low levered companies and companies with high growth opportunities. The impact swings to be insignificant in case of large, high levered firms and firms with low growth opportunities.

Table 4.4 indicates the results of regression model where leverage ratio of 100 firms whose listed in KSE regressed on a measure of judicial efficiency.JE plus other explanatory variables are taken from the duration of 2010 to 2012.The dependent variable is LEV2, that is measure as ratio of total-debts to total assets. To measure the SIZE use the natural logarithm of total assets. TANG as the ratio of net fixed assets to total assets. Ratio of net income to total asset as PROF.MVBV is denoted with GROWTH and uses the ratio of market value per share to book value per share.

At last, see the judicial efficiency impact on leverage ratios of the firm. The JEi is statistically insignificant at $5 \%$ level $(\mathrm{t}=-0.610, \mathrm{p}>0.05)$ in LEV1 and $(\mathrm{t}=-1.293$, $\mathrm{p}>0.05)$ in LEV2.The coefficient of JE is (-0.002) in LEV1 and is (-0.004) in LEV2, that indicates the negative relationship between JE and with both LEV1 \& LEV2. The statistical insignificance demonstrates that its standard error is more than the adequate edge level. As JE increases by one standard deviation, the LEV1 will decrease by 0.002 and LEV2 will decrease by 0.004 with standard deviation, that's show the in-efficiency of courts.

\section{CONCLUSIONS}

This study aims to explore (a) Capital market development, highlighting the significance of efficient judicial system in Pakistan, (b) To highlight the significance of particular characteristics of the firm on which the efficiency of the judicial system is not high or in efficient in financing decision and (c) in Pakistan for capital market development, highlighting the significance of efficient judicial system and different firms particular aspects on financial leverage. Data for this study is taken from Balance Sheet Analysis Of 100 Companies (Nonfinancial) Listed at KSE issued by State Bank of Pakistan (SBP) for 2010-2012.

To test the relationship among the variables under study the multiple regression models were applied. The results of the explanatory variables demonstrate that the size of the firm, tangibility of assets and profitability \& growth all have a significant effect on leverage ratios; the firm's size has greater economic impact on financial leverage. The association among efficient judicial system and financial leverage is statistically insignificant. This may be because of the influence of the organization, which means that the judiciary does not affect the effectiveness of all organizations equally particular possibility firm-specific characteristics are included in the study as a explanatory variables, which support to measure judicial efficiency impact on leverage ratios.

The co-efficient of regression results indicate that judicial efficiency (independent variable) and explanatory variables with leverage ratios (dependent variable) are negatively associated except variable Growth (explanatory variable). Only growths have positive correlation with financial leverage.

Other variables reflect the regression results in the light of the pecking order theory, where exists negative relationship among debt and profitability of companies. When companies become more profitable, expand the size of the company and try to generate internal financing by taking advantage of their tangible assets and to avoid external financing, which is the result of low leverage. In Pakistan, the majority of large-sized and the greater profitable firms with low leverage ratios because they prefer to generate financing from internal sources through the use of own tangible assets. Religious concept is also the main reason of low leverage. Pakistan is a Muslim country; companies do not prefer to take the debt owed to the point of interest opinion, because interest isn't allowed in Islam.

In the end, results from the tests show that the judicial efficiency and leverage ratio have negative and insignificant relationship. Leverage ratio is low in large firms because there is inefficient judicial system in Pakistan. But results showed that the inefficiency of 
the judicial system isn't the main cause of low leverage ratio. However, it doesn't imply that judiciary system has doesn't any effect on leverage ratios.

\section{Policy Implications}

Leverage regressions results have crucial implications for development of capital-market and financial deepening.

a) Improvement of the judicial system in Pakistan that will increase the leverage ratios of both large and small size firm

b) Change financing models and make new policies for debts that are according to Islamic point of view. That increases the leverage ratios of firm.

\section{REFERENCES}

Aghion, P., \& Bolton, P. (1992). An incomplete contracts approach to financial contracting. The Review of Economic Studies, 59(3), 473-494.

Auerbach, A. J. (1979). Share valuation and corporate equity policy. Journal of Public Economics, 11(3), 291-305.

Bae, K.-H. and Goyal, V. K. (2009) Creditor Rights, Enforcement, and Bank Loans. The Journal of Finance, 64(2), 823-860

Barro, R. J. (1976). The loan market, collateral, and rates of interest. Journal of Money, Credit and Banking, 8(4), 439-456.

Besanko, D., \& Thakor, A. V. (1987). Collateral and rationing: sorting equilibria in monopolistic and competitive credit markets. International Economic Review, 671-689.

Bester, H. (1985). Screening vs. rationing in credit markets with imperfect information. The American Economic Review, 75(4), 850-855.

CHAN, Y. S., \& Thakor, A. V. (1987). Collateral and competitive equilibria with moral hazard and private information. The Journal of Finance, 42(2), 345-363.

Chan, Y. S., \& Kanatas, G. (1985). Asymmetric valuations and the role of collateral in loan agreements. Journal of Money, Credit and Banking, 17(1), 84-95.

Chang, C. 1989. Debt maturity structure and bankruptcy. Working paper. Minneapolis: University of Minnesota

Claessens, S., Djankov, S., \& Klapper, L. (2003). Resolution of corporate distress in East Asia. Journal of Empirical Finance, 10(2), 199-216

Coco, G. (2000). On the Use of Collateral. Journal of Economic Surveys, 14(2). 191-214

Diamond, D. W. (1991). Monitoring and reputation:
The choice between bank loans and directly placed debt. Journal of Political Economy, 689-721.

Eaton, J., \& Gersovitz, M. (1981). Debt with potential repudiation: Theoretical and empirical analysis. The Review of Economic Studies, 48(2), 289-309.

Fama, E. F. (1980). Agency Problems and the Theory of the Firm. The Journal of Political Economy, 288307.

Flannery, M. J. (1986). Asymmetric Information and Risky Debt Maturity Choice. Journal of Finance, 41(1), 19-37

Galindo, A. J. (2001). Creditor rights and the credit market: where do we stand?.

Hart, O. and J. Moore (1999). Foundations of Incomplete Contracts. Review of Economic Studies, 99(1), $115-138$

Jaffee, D. and T. Russell (1976). Imperfect Information, Uncertainty, and Credit Rationing. The Quarterly Journal of Economics, 90(4), 651-666

Jappelli, T., M. Pagano and M. Bianco (2005). Courts and Banks: Effects of Judicial Enforcement on Credit Markets. Journal of Money, Credit and Banking, 45, 123-145

Jensen, M. C., \& Meckling, W. H. (1976). Theory of the firm: Managerial behavior, agency costs and ownership structure. Journal of Financial Economics, 3(4), 305-360.

La Porta, R., F. Lopez-de-Silanes, A. Shleifer and R. Vishny (1997). Legal Determinants of External Finance. Journal of Finance, 52(3), 1131-1150

La Porta, R., F. Lopez-de-Silanes, A. Shleifer and R. Vishny (1998). Law and Finance. Journal of Political Economy, 106(6), 1113-1155

La Porta, R., Lopez-de-Silanes, F., Shleifer, A., \& Vishny, R. (2000). Investor protection and corporate governance. Journal of Financial Economics, 58(1), 3-27.

Laeven, L., \& Majnoni, G. (2003). Does judicial efficiency lower the cost of credit?. World Bank Policy Research Working Paper, (3159).

Magri, S. (2006). Debt maturity of Italian firms. Bank of Italy Economic Research Paper, (574).

Modigliania, F., \& Perottib, E. (1997). Development of Security Markets.Manage. Decis. Econ, 18, 519528.

Myers, S. C. (1977). Determinants of corporate borrowing. Journal of Financial Economics, 5(2), 147-175.

Myers, S. C. (1984). The Capital Structure Puzzle. Journal of Finance, 39(3), 575-592

Pettit, R. R. and R. F. Singer (1985). Small Business Finance: A Research Agenda. Financial Management, 14, 47-60

Rajan, R. G., \& Zingales, L. (1995). What do we know 
about capital structure? Some evidence from international data. The Journal of Finance,50(5), 1421-1460.

Shleifer, A. and R. Vishny (1997). A Survey of Corporate Governance. Journal of Finance, 92 (2), 737-783

Smith, C. W., \& Warner, J. B. (1979). On financial contracting: An analysis of bond covenants. Journal of Financial Economics, 7(2), 117-161.

Stiglitz, J. E., \& Weiss, A. (1981). Credit rationing in markets with imperfect information. The American
Economic Review, 71(3), 393-410.

Titman, S., \& Wessels, R. (1988). The determinants of capital structure choice. The Journal of Finance, 43(1), 1-19.

Townsend, R. M. (1979). Optimal contracts and competitive markets with costly state verification. Journal of Economic Theory, 21(2), 265-293.

Whited, T. M. (1992). Debt, liquidity constraints, and corporate investment: Evidence from panel data. The Journal of Finance, 47(4), 1425-1460. 